\title{
Mobile Learning in Business English its Effect to South American Students' Learning Styles in the COVID 19 Pandemic Era: Its Economic Implications
}

\author{
JOEL ALANYA-BELTRAN ${ }^{1}$, JEIDY PANDURO-RAMIREZ ${ }^{2}$ \\ ${ }^{1}$ UNIVERSIDAD TECNOLÓGICA DEL PERÚ, PERU. E-mail: c18121@utp.edu.pe \\ UNIVERSIDAD TECNOLÓGICA DEL PERÚ, PERU, E-mail: c21289@utp.edu.pe
}

\begin{abstract}
The adoption of M-learning and perceptual learning style preferences of South American EFL learners in a business English course were studied empirically. The descriptive correlational research design was used in this study. Data were gathered from 125 South American EFL students who were carefully sampled among 184 mobile-phone-wielding students registered in a business English program at a selected South American university. The Perceptual Learning Style Preference Questionnaire and Mobile Learning Questionnaire (MLQ) were used in the study (PLSPQ). The data revealed that students in a business English course have a high level of M-learning adoption. It was discovered that respondents favor auditory learning, visual learning, individual learning, tactile learning, and group learning with kinesthetic learning receiving the least attention. When students are grouped by gender and age, test results show that male respondents had a stronger appeal to the utility, facilitating conditions, enjoyment, behavioral intention, and acceptability of M-learning than female respondents. Without regard for their age, respondents acknowledged the benefits of using M-learning in their business English courses. Similarly, when the respondents are grouped by gender, there are no substantial differences in preferred learning styles are detected. However, the younger respondents prefer group learning, whilst the older respondents prefer individual learning. Finally, a link was discovered between M-learning usage and students' preferred learning styles. The positive link implies that the greater number of students who utilize M-learning, the more learning style preferences they have for the group, tactile, visual, auditory, kinesthetic, and group learning tasks. This paper discusses the theoretical and educational consequences.
\end{abstract}

Keywords: Mobile learning; Education; COVID-19.

JEL Classification: M00, M10, M19

Received: June 07, 2021

Accepted: October 01, 2021 


\title{
Mobile Learning en Inglés de Negocios su Efecto en los Estilos de Aprendizaje de los Estudiantes Sudamericanos en la Era de la Pandemia COVID 19: Sus Implicaciones Económicas
}

\author{
JOEL ALANYA-BELTRAN ${ }^{1}$, JEIDY PANDURO-RAMIREZ ${ }^{2}$ \\ ${ }^{1}$ UNIVERSIDAD TECNOLÓGICA DEL PERÚ, PERU. E-mail: c18121@utp.edu.pe \\ ${ }^{2}$ UNIVERSIDAD TECNOLÓGICA DEL PERÚ, PERU, E-mail: c21289@utp.edu.pe
}

\begin{abstract}
RESUMEN
Se estudió empíricamente la adopción del M-learning y las preferencias de estilo de aprendizaje perceptivo de los alumnos sudamericanos de EFL en un curso de inglés comercial. En este estudio se utilizó el diseño de investigación descriptiva correlacional. Se recogieron datos de 125 estudiantes sudamericanos de EFL que fueron muestreados cuidadosamente entre 184 estudiantes que utilizaban el teléfono móvil, inscritos en un programa de inglés comercial en una universidad sudamericana seleccionada. En el estudio se utilizaron el Cuestionario de Preferencia de Estilos de Aprendizaje y el Cuestionario de Aprendizaje con Móviles (PLSPQ). Los datos revelaron que los estudiantes de un curso de inglés comercial tienen un alto nivel de adopción del M-learning. Se descubrió que los encuestados favorecen el aprendizaje auditivo, el aprendizaje visual, el aprendizaje individual, el aprendizaje táctil y el aprendizaje en grupo, siendo el aprendizaje cinestésico el que recibe menos atención. Cuando se agrupa a los estudiantes por género y edad, los resultados de las pruebas muestran que los encuestados masculinos apelaron más a la utilidad, las condiciones facilitadoras, el disfrute, la intención de comportamiento y la aceptabilidad del M-learning que las encuestadas. Sin tener en cuenta su edad, los encuestados reconocieron las ventajas de utilizar el M-learning en sus cursos de inglés comercial. Del mismo modo, cuando los encuestados se agrupan por género, no se detectan diferencias sustanciales en los estilos de aprendizaje preferidos. Sin embargo, los encuestados más jóvenes prefieren el aprendizaje en grupo, mientras que los mayores prefieren el aprendizaje individual. Por último, se ha descubierto una relación entre el uso del M-learning y los estilos de aprendizaje preferidos por los estudiantes. La relación positiva implica que cuanto mayor es el número de estudiantes que utilizan el M-learning, más preferencias de estilo de aprendizaje tienen para las tareas de aprendizaje en grupo, táctil, visual, auditivo, cinestésico y grupal. En este artículo se analizan las consecuencias teóricas y educativas.
\end{abstract}

Palabras clave: Aprendizaje móvil; Educación; COVID-19.

Clasificación JEL: M00, M10, M19

Recibido: 07 de Junio de 2021

Aceptado: 01 de Octubre de 2021 


\section{Introduction}

With the pandemic engulfing the world and impacting more than 1.2 billion learners who were outside the classroom in 186 nations (Barrafrem, et al, 2020, Talwar, et al, 2021), technology has shown to be nothing short of a godsend in the day-to-day running of life. People's lives have been drastically altered as a result of technological advancement and the internet, which has also resulted in significant changes in a variety of areas. Technology's arrival in the modern era ushered in substantial changes in the educational scene. Education 4.0, the next educational paradigm, demands students and teachers in order to be familiar with cutting-edge technical devices to provide effective instruction. Technology integration and application in the classroom are required components of the current educational system of today. With the quick proliferation of smartphones, laptops, and desktop computers, the conventional way of learning has been reinvented, allowing students to engage in infinite and borderless learning experiences.

The implementation of Mobile Learning or M-Learning in the Higher Education environment is currently attracting educational scholars to investigate its effectiveness and suitability in the educational setting (Yuan, et al, 2021). M-Technology gives educators and students at different universities approach to data for learning and decision-making (Elsalem, et al, 2020). Mobile learning has blended, ubiquitous, private, collaborative, and interactive elements, as well as instant information that enables learners in progressing on their own progress and leisure, allowing them in feeling the delight of real learning (Tkachuk, et al, 2020). M-learning, according to the authors, is an important primary or supplementary learning tool that complements education due to its ability to provide a large number of learning possibilities. The M-learning can be deemed as a possible instruction mode for improving the process of education. M-learning is now being implemented in many higher education systems throughout the world.

M-learning, regardless of its benefits and popularity, if students are hesitant to use it in their studying, the potential advantages cannot be realized to their full potential, given that purposeful and practical learning is defined by the learners' active participation in self-regulated learning (Laksana, 2021). As a result, further investigation is necessary on how students display M-learning adoption and its association with their preferred modes of instruction in Business English learning in this study. This endeavour aims to clarify the previously given anomalies in Southamerican EFL learners' learning styles, as well as their relevance to M-learning adoption. Previous research has suggested that one's behavioral disposition, inclination, and preferences are a significant driver of learning (Khan, et al, 2015, Muñozet al, 2020). Varied learners have different inclinations and learning styles, which means they have varying levels of technological adoption (Martin ,2020). It eventually led to a more thorough examination of the relationship between M-learning and style of learning adoption in a corporate English course.

The Technology Acceptance Model or TAM serves as the foundation for this investigation. This information systems theory explains how people accept and use technology on the basis of its utility, simplicity of use, enabling conditions, and behavioral conditions (Chtourou \& Souiden, 2010). Due to its adaptability, soundness, and simplicity, TAM is recognized as a quality model for measuring information system adoption and acceptability within the framework of mobile learning.

The current research examined the application of mobile learning in a business English course for South American EFL students, led by the TAM aspects. Thus, improved mobile learning implementation in language lessons will boost the learning performance of the students. Additionally, it will give critical language instructors' interventions on how to combine properly M-learning into the classroom while maximizing student engagement. The utility and easiness with which South American EFL students perceived technology defined their level of computer and technical literacy, which is targeted at lifelong skills and global proficiency. As a result, higher education institutions are accountable for the development of highly qualified and capable human resources. Additionally, they help us identify the factors that influence students' technological adoption and literacy levels prior to adopting treatments aimed at developing technological systems. Universities must do an analysis of the appropriate use of 
M-learning in order to establish the criteria that will allow its deployment and use for student development.

Numerous recent studies have demonstrated that mobile learning is widely accepted across countries and ethnicities, demonstrating its benefits in modern-day college classrooms across a variety of learning domains, including language, science, medical, and social sciences (Naciri, et al, 2020, Saikat, et al, 2021, Sitar-Tăut, 2021, Tkachuk, et al, 2020). Crompton and Burke (2018) discovered that the bulk of 72 research publications produced in reputed internal journals from 21 nations concentrated on the influence of M-learning on learner performance and success. Additionally, they noted that language learning and instruction are the most often researched study issue when $\mathrm{M}$ learning is used in conjunction with varied instructional modalities. Despite the popularity of mobile learning as a means of increasing student academic attainment, the research gap surrounding $\mathrm{M}$ learning and learning styles remains relatively unexplored. It motivated the current research to contribute to the presently available body of knowledge regarding the relationship between both of these factors and the setting of business English learning.

How the students' learning style preferences are associated with the adoption of M-learning was looked by the present study. Learning styles have been claimed as significant determinants of how students learn and acquire the English language, which fundamentally influences their learning outcomes. Bernacki, et al (2020) noted that awareness of the learning styles of students will let teachers of language to effectively initiate activities that meeting the demands of every learner. Classifying and discerning students' differences will help them to develop their capacity at an optimum level. The notable types of learning styles this present study adapted are those of Reid's (1987) Perpetual Learning Style preferences classified into kinesthetic, group, individual, visual auditory, and tactile. These learning styles are the typical and accessible, as well as extensive research types of learning styles in language teaching. Its acceptability and popularity attribute to its simplicity, validity, reliability, and ease of utilization (Islam, 2011, Ge, 2021, Turri, 2020). Additionally, appropriate identification of learners' learning styles will guide language teachers on how to attack language lessons by way of planning and designing teaching modalities that are learner-centered. Therefore, limited awareness of learners' characteristics, particularly their learning styles, will not facilitate better learning opportunities, motivation, and outcomes.

At present, studies on learning techniques in second language learning and acquisition are still inconclusive, requiring further investigations across personal and cultural backgrounds (Khampirat, 2021, Khedr, et al, 2019, Magulod Jr, 2019, Taufina, et al, 2019). Moreover, there are limited studies conducted on how learners differ in learning styles when they are being presented with information. Furthermore, empirical studies relating to learning styles and mobile learning are still limited. This study examined how the students' preferred learning styles relate to the level of adoption of mobile learning.

Charting the problem in Asia as a developed nation of the world requires to put premium emphasis on business English language learning. English presently dominates the world market as the international language, which challenges language teachers to find effective ways and means in teaching business English among universities. The present trend of economic flow, coupled with technological advancement and development, has brought society to venture into the knowledgebased commercial approach. The creation, innovation, and development of services and products necessitate novel approaches to business management for investment prospects, and these will not be achieved without the active channels of communication in the global landscape. Asia recognizes the English language as its bridge to the future (Pan \& Patel, 2018; Xie, 2019).

To emphasize, earlier research on mobile learning in the South American setting has been conducted. The study identifies a huge research gap for teachers of language in determining the association between styles of learning and the adoption of m-learning in the setting of a select institution in Asia. The study aims in providing an overview of mobile learning and to shed light on the observed differences in the characteristics of personal learning of South American students. Therefore, it is appropriate and necessary to develop an understanding of how the students adopt through the 
utilization of M-learning in business English courses, as well as to match their level of adoption to their preferred learning methods, in order to maximize their human flourishing.

\subsection{Objectives of The Study}

To shed some light on the following topics, this document served as a guide. Students in South America's EFL programs believe that M-Learning is being implemented in their Business English courses? Does the age and gender of students have a significant impact on their adoption of $\mathrm{M}$ Learning? What are the students' most preferred methods of learning? Are there significant differences in the preferred learning styles of students when divided by age and gender? The use of M-learning and business English language students' choice of learning method may have some correlation.

\subsection{Research Hypotheses}

1. There is a substantial variation between the M-Learning uptake when grouped according to gender.

2. There is a substantial variation between the M-Learning uptake when grouped according to age.

3. There is a substantial variation between the styles of learning and gender.

4. There is a substantial variation between styles of learning and age.

5. There is a substantial variation between the M-Learning uptake and the learning style preferences of the students in the business English language course.

\section{Methodology}

\subsection{Research Design}

Students in a business English course talk about their learning preferences and how they utilize mobile devices to learn in this descriptive correlational study. Students' mobile learning flexibility and their chosen teaching approaches may both be explained by descriptive competence. Using standardized correlating tests to create a strong pattern of correlation, descriptive crosssectional correlational research has shown to be an efficient way to discover the relationship between variables (Fisher, 1992). In the case of studying mobile learning and learning styles, descriptive correlational research shows strong links between the variables being studied.

\subsection{Research Participants, Sampling Procedure, and Ethical Considerations}

At the University of Asia's College of Foreign Languages, there were 125 South American EFL students. Class members were chosen based on the following two criteria: The following are the prerequisites for a typical College of Foreign Languages business English student: You need two things: (1) to be enrolled in business English courses, and (2) to have been taught and exposed to M-learning during the semester of study. Table 1 displays the total number of people who answered the survey and their response percentages. When seen as a whole, the proportions of men and women are almost the same (51 percent). (On $49 \%$ of the occasions) As a result, there was no longer any discrimination in comparing men's and women's learning styles or the usage of M-learning. People under 20 make up $19 \%$. Those 21 to 25 make up another $20 \%$. Those 31 to 35 years old make up $35 \%$ of all individuals who responded to our survey (the median age was 21 years old) (31 percent). just $8 \%$ of the time $A$ stratified random selection technique was used to choose 184 Business English students from the entire community of participants. With Raosoft, a sample size of 125 items was generated, with a $5 \%$ margin of error, an overall confidence level of $95 \%$, and a $50 \%$ response distribution. Raosoft computed the sample size. The following URL provided access to Raosoft's online software: To avoid Type I and Type II mistakes, Raosoft has created sampling software that determines the power of given sample size and alpha level. After consulting with university officials, the registrar's office sought access to the 
whole class roster. They used a technique known as systematic sampling to accomplish their goal. A variety of ethical concerns influenced the results of this study. The university's ethics committee approved the survey and required survey participants to sign permission and privacy papers. Second, the researcher provided participants with an overview of the study's objectives before delivering the instruments. Last but not least, the institution and respondents' privacy were protected by using pseudonyms.

\subsection{Research Instruments}

The Mobile Learning Questionnaire (MLQ) and the Perceptual Learning Style Preference Questionnaire were used in this study to address the survey's research questions (PLSPQ).

\subsection{Mobile Learning Tool}

The MLQ was previously used to assess uptake of M-learning (Kalloo \& Mohan, 2012, Tan \& Liu, 2004). There were an equal number of items for each of the five criteria: utility, acceptability, subjective pleasure, enabling circumstances, and behavioral objectives. When it came to agreeing or disagreeing with the survey's findings, the respondents' Likert scale went from 1 to 5 . This instrument has a Cronbach's alpha of 0.85 .

\subsection{Perceptual Learning Style Preference Questionnaire (PLSPQ)}

On the other side, to ascertain respondents' preferred learning styles, the Reid (1984) Perceptual Learning Style Preference Questionnaire (PLSPQ) was used. The test contains 30 statements, each of which contains a question related to one of the following learning styles: tactile, visual, group, individual, auditory, or kinesthetic.

\subsection{Procedure}

Generally, this study was conducted for a three-month timeline. The process for collecting research data lasted three weeks. Prior to the formal data collection phase commencing, the first week was spent obtaining consent and permission from the university authority to conduct the study. The second week saw the publication of a notice to proceed with the research. The researcher identified respondents using the study's inclusion criteria with the assistance of two business language professors from the College of Foreign Languages after getting the required approvals. Similarly, regular and scheduled appointments with students were made in preparation for another week's formal gathering. The participants were informed of the research's goal and objectives. The researcher administered the two-study equipment with the necessary permits and cooperation to minimize scheduling conflicts. The researcher adhered rigorously to research ethics considerations. Following the collection of student replies, they were coded and subjected to one month of data cleaning and statistical analysis. Finally, another month was spent on data analysis, interpretation, and report writing. Students' chosen learning methods and the degree of M-learning adoption were studied using basic descriptive statistics such as frequency count, percentage distribution, weighted mean and standard deviation. The independent sample t-test and one-way Analysis of Variance (ANOVA) were used to examine gender and age variations in the adoption of M-learning and learning styles. If a significant age difference exists in respondents' M-learning adoption and learning methods, the Post Hoc Tukey Honest Significant Difference (HSD) test was used to find out. This test pinpoints exactly where the differences exist between respondents. M-learning and student preferences for perceptual learning methods were shown to be significantly linked using the Pearson correlation coefficient. 


\section{Results and Discussion}

\section{Research Question 1. Perception of South American EFL learners on M-Learning}

Table 1 shows how many South American EFL students are using M-learning in their business English classes. Respondents have adopted M-Learning to a great degree, as shown by the calculated mean $(M=3.83, S D=0.614)$. The five categories of usefulness, acceptability, perceived pleasure, enabling conditions, and behavioral goals all showed a high degree of adoption of mobile learning $(\mathrm{M}=3.78, \mathrm{SD}=0.9 .66), \mathrm{M}=3.80, \mathrm{SD}=1.04, \mathrm{M}=3.80, \mathrm{SD}=1.04$, and behavioral intentions).

Table 1 Adoption of Mobile Learning in Business English Language Course

\begin{tabular}{|c|c|c|c|}
\hline Domains & $\begin{array}{c}\text { Mean } \\
(n=125)\end{array}$ & SD & $\begin{array}{l}\text { Descriptive } \\
\text { Interpretation }\end{array}$ \\
\hline $\begin{array}{l}\text { Usefulness of Mobile learning to Business English } \\
\text { Language Course }\end{array}$ & 3.78 & .966 & High \\
\hline $\begin{array}{l}\text { Acceptability of Mobile learning to Business English } \\
\text { Language Course }\end{array}$ & 3.80 & 1.04 & High \\
\hline $\begin{array}{l}\text { Perceive Enjoyment of Mobile learning to Business } \\
\text { English Language Course }\end{array}$ & 3.85 & .959 & High \\
\hline $\begin{array}{l}\text { Facilitating Conditions to Business English Language } \\
\text { Course }\end{array}$ & 3.86 & .910 & High \\
\hline $\begin{array}{l}\text { Behavioral Intention to Business English Language } \\
\text { Course }\end{array}$ & 3.88 & .894 & High \\
\hline Grand Mean & 3.83 & .614 & High \\
\hline
\end{tabular}

Legend: Strongly Agree/ Very High ${ }^{a}$ (4.20-5.00); Agree/ High ${ }^{\text {b }}$ (3.40-4.19); Undecided/ Moderate ${ }^{\text {c }(2.60-3.39) ; ~ D i s a g r e e / ~ L o w ~}{ }^{\text {d }}$ (1.80-2.59); strongly Disagree/ Very Low ${ }^{\mathrm{e}}$ (1.00-1.79)

Mobile learning was found to be well accepted in Business English classes among South American EFLs, according to the findings of the present research. That is to say, M-learning makes learning more meaningful, collaborative, and engaging for students, helping them better understand their subject matter. They learn about the advantages of M-learning, which expands their horizons in terms of developing their abilities. When it comes to M-learning, experts say it's an effective way of helping students learn more while also creating good interactions between them and their teachers (Oyelere, Set al, 2016).

The high evaluations provided by South American EFL students show the use and acceptance of mobile learning in a business English course. This metric reveals that participants credited $\mathrm{m}$-learning with helping them complete their learning tasks faster and more efficiently. They also thought of themselves as more productive as a result of incorporating M-learning into their regular tasks. Mlearning is often helpful in their studies for these students. While this result is surprising, it confirms earlier studies showing how useful and popular mobile learning is among university students throughout Asia, Australia, the United States, and Europe (Al-Azawei \& Alowayr, 2020, Al-Emran, et al, 2020, Jossan, et al, 2021). When it comes to language acquisition, research shows that mobile learning has a substantial impact on pupils in South America's mastery of the language's four macro skills and assessment (Mutambara, \& Bayaga, 2021, Bernacki, et al, 2020). Thus, factors like as satisfaction with mobile learning and behavioral intention from the Technology Acceptance Model (TAM) are included in this research. Participants evidently value both qualities highly, showing an openness to M-learning in an English course for business. Utilizing m-learning was shown to be enjoyable for students, with both a belief and an intention to continue using it in future learning experiences. As a result, our findings contribute to the growing body of research on the effects of M-learning on students' attitudes and control beliefs. Finally, respondents give high marks to the enabling circumstances for adopting M-learning in business English courses when it comes to how well they work. South American respondents have the resources, knowledge, and environmental support needed to effectively implement M-learning, despite various technical difficulties associated with effectively delivering Elearning modalities such as internet speed, software issues, and user-friendliness of technological tools. This shows that so the university and teachers offer a beneficial e-learning environment for improving business English learning. 


\section{Research Question 2. How does the adoption of M-Learning differ when students are categorized by age and gender?}

Table 2 shows how many students in the Business English language course are using M-learning. There are significant differences in acceptability $\left(p=0.00^{* *}\right)$ and enjoyment $(p=0.00 * *)$, facilitating conditions $\left(p=0.00^{* *}\right)$ and behavioral intentions in favor of male respondents when gender is taken into account separately, with computed $p$ values less than the 0.01 alpha level in favor of male respondents. At the same time, there is no difference in the usefulness of M-learning ( $p=0.624 \mathrm{~ns}$ ). There is a significant disparity between male and female respondents in their use of M-learning, according to the statistics. As a result, the assumption that m-learning adoption differs significantly by gender is recognized. The results show that regardless of age, students were able to attain a high degree of M-learning adoption in a business English language course, suggesting that age is not a relevant grouping variable for M-learning adoption. Because of this, the theory that m-learning adoption differs significantly by age group is ruled out.

Table 2 Test of Differences on the adoption of M-Learning in the Business English Language course when grouped according to gender and age

\begin{tabular}{lll}
\hline Adoption of M-Learning & $\begin{array}{l}\text { Gender } \\
\text { p-value }\end{array}$ & $\begin{array}{c}\text { Age } \\
\text { p-value }\end{array}$ \\
\hline Usefulness of Mobile learning to Business English Language & $0.624 \mathrm{~ns}$ & $0.017 \mathrm{~ns}$ \\
Course & & $0.900 \mathrm{~ns}$ \\
Acceptability of Mobile learning to Business English Language & $\mathbf{0 . 0 0 0}$ & \\
Course & & $0.340 \mathrm{~ns}$ \\
Enjoyment of Mobile learning to Business English Language & $\mathbf{0 . 0 0 0 * *}$ & $0.340 \mathrm{~ns}$ \\
Course & $\mathbf{0 . 0 0 0 ^ { \star \star }}$ & $0.779 \mathrm{~ns}$ \\
\hline Facilitating Conditions to Business English Language Course & $\mathbf{0 . 0 0 1 ^ { \star \star }}$ & \\
\hline
\end{tabular}

Note: ${ }^{*} p<0.05 ;{ }^{* *} p<0.01 ;{ }^{* * *} p<0.00$

ns $=$ not significant

In the current study, factors like as gender and age were looked at in relation to mobile learning uptake in a South American EFL business English course. When it comes to adopting mobile learning technologies, age and gender matter since they have an impact on how effectively the e-learning modality is used (Asongu, et al, 2021, Ranjeeth, et al, 2020). There was a significant gender gap in the findings, with men being more open-minded and enthusiastic about mobile learning than women. According to the findings of the study, males are more prone than women to make use of technological devices. Women, on the other hand, are less inclined than males to try out new technologies. Women are less likely than males to seek professions in computer science and technology because of the higher degree of anxiety women feel, according to the findings. Male South American EFL students use Mlearning at a higher rate than female students in business English courses. When age is taken into consideration, there are no significant variations in the adoption of M-learning. Mobile learning in an English language business English course may benefit students of any age, as this study shows. Using M-learning in corporate English courses allowed these students to collaborate better, establish personal connections, and make new friends.

\section{Research Question 3. What are the students' preferred learning styles?}

Table 3 depicts how individuals choose to study as a result of this. It's important to understand how students think about and value learning, so we questioned them about their preferred learning styles. Instructors will be given the knowledge they need to better serve their students as a result. Teaching styles that came out on top in our poll (see Table 3) were: In spite of the popularity of the visual learning technique $(M=4.43, S D=0.72)$, group learning $(M=3.81, S D=0.81)$ is also widely used. Also included are techniques such as self-study $(\mathrm{M}=3.90, \mathrm{SD}=0.71)$ and approaches such as tactile and auditory learning $(M=3.80, S D=0.70)$. A small percentage of participants $(M=3.24 ; S D=0.97)$ also shown a preference for kinaesthetic learning methods. 
Table 3 Learning Style Inclinations of the Respondents

\begin{tabular}{llcll}
\hline \multicolumn{1}{c}{ Domains } & $\begin{array}{c}\text { Mean } \\
(\mathbf{n = 1 2 5})\end{array}$ & SD & Descriptive Interpretation \\
\hline 1. & Visual & 4.43 & 0.72 & Very High \\
2. & Auditory & 4.13 & 0.81 & High \\
3. & Kinesthetic & 3.24 & 0.97 & Moderate \\
4. & Group & 3.81 & 0.81 & High \\
5. Tactile & 3.80 & 0.80 & High \\
6. Individual & 3.90 & 0.82 & High \\
& Grand Mean & $\mathbf{3 . 8 2}$ & $\mathbf{0 . 3 1}$ & High \\
\hline
\end{tabular}

Legend: Strongly Agree/ Very High $^{\text {a }}$ (4.20-5.00); Agree/ High ${ }^{\text {b }}$ (3.40-4.19); Undecided/ Moderate ${ }^{\mathrm{c}}$ (2.60-3.39); Disagree/ Low ${ }^{\mathrm{d}}$ (1.80-2.59); strongly Disagree/ Very Low ${ }^{\mathrm{e}}(1.00-1.79)$

Researchers have to reevaluate the preferences of South American students because of the shifting learning techniques used by EFL students in the region. To find out which teaching techniques worked best for each set of pupils, researchers looked at their preferred ways of learning. In the business English course, most South American EFL students benefit from multimodal learning, which emphasizes visual and auditory techniques as well as team-based and individual approaches to teaching. According to the pupils, collaborative, immersive, and hands-on teaching techniques were their top choices. It's no secret that students in business English classes prefer visual learning techniques including training materials, videos, and PowerPoint presentations. Podcasts, teacher-led lectures, and other audio-based materials may be helpful to students who prefer auditory learning while this is going on as well. A strong preference for tactile learning follows, with respondents indicating that using hands-on learning materials in a corporate English language training may enhance their comprehension. According to the survey findings, collaboration, learning interaction, and selfdiscovery learning may all be used to meet the learning preferences of both individuals and groups.

Research Question 4. Is there a substantial variation between the preferred learning style when grouped according to age and gender?

Learning styles such as visual, auditory, and kinaesthetic do not vary significantly when gender is included as a grouping variable. Learning styles such as collaborative or individual may be noticed. A substantial difference in learning methods and gender between men and women has been ruled out, according to this finding. In other words, they're saying that both sexes can learn from different teaching methods. Table 5 shows that respondents under the age of 21 and 21-25 prefer group learning over those between the ages of $26-30$ and $31-25$, indicating that age is a factor in learning style.

Table 4 Test of Differences on the Learning Styles Preferences of Students in the Business English Language course when grouped according to gender and age

\begin{tabular}{lcc}
\hline \multicolumn{1}{c}{ Learning Style Preferences } & Gender & $\begin{array}{c}\text { Age } \\
\text { p-value }\end{array}$ \\
\hline Visual & p-value & $0.678 \mathrm{~ns}$ \\
Auditory & $0.456 \mathrm{~ns}$ & $0.654 \mathrm{~ns}$ \\
Kinesthetic & $0.256 \mathrm{~ns}$ & $0.654 \mathrm{~ns}$ \\
Group & $0.234 \mathrm{~ns}$ & $0.003^{*}$ \\
Tactile & $0.654 \mathrm{~ns}$ & $0.004^{*}$ \\
Individual & $0.432 \mathrm{~ns}$ & $0.007^{*}$ \\
\hline
\end{tabular}

Note: ${ }^{*} p<0.05 ;{ }^{* *} p<0.01 ;{ }^{* * *} p<0.00$

ns $=$ not significant

People between the ages of 26 and 30 prefer independent study, which is surprising. There is no difference in preference between young and old learners when it comes to learning styles. As far as South American EFL learners' preferences for learning styles go, there is no statistically significant difference between the genders when it comes to the learning styles they choose. This suggests that both men and women have similar learning styles while taking a business English course. This finding supports earlier studies that found no variation in learning preferences between men and women based on gender (Abouzeid, et al, 2021, Navarro,et al, 2020). Because of this, younger respondents are more likely to choose group learning because of the wide age gap. Younger respondents are more accessible and cooperative in their learning methods, so this suggests. A similar preference for self- 
directed learning may be seen among the elderly population, where respondents say they prefer a more individualized approach to education. All three senses were equally valued by the participants regardless of their age. According to the results of the research, multimodal teaching is highly valued by South American EFL students. The way a student learns is critical when it comes to foreign language teaching. South American EFL students who are taking business English classes may benefit from understanding the common learning methods utilized by other EFL students. Language instructors will acquire a better knowledge of how to coordinate their teaching to promote purposeful and practical education via the execution of meaningful learning activities that are suited to learners' dispositions at various levels of preference since English is prevalent throughout Asia.

Research Question 5. Is there a substantial variation between the M-Learning uptake and the learning style preferences of the students in the business English language course.

Students' $\mathrm{m}$-learning adaptations and their learning preferences were examined by researchers in this study. A knowledge vacuum exists when it comes to the relationship between student learner characteristics and mobile learning in business English courses, particularly in the South American EFL context. This research will contribute to closing that knowledge gap.

Table 5 Relationship between students' Adaptability of Mobile Learning in Business Language Course and their learning Styles

\begin{tabular}{|c|c|c|c|c|c|c|}
\hline $\begin{array}{l}\text { Adoption of } \\
\text { Mobile Learning } \\
\text { to Business } \\
\text { English } \\
\text { Language } \\
\text { Course }\end{array}$ & $\begin{array}{l}\text { Visual } \\
\text { r value }\end{array}$ & $\begin{array}{l}\text { Auditory } \\
\text { r value }\end{array}$ & $\begin{array}{l}\text { Kinesthetic } \\
\text { r value }\end{array}$ & $\begin{array}{l}\text { Group } \\
\text { r value }\end{array}$ & $\begin{array}{l}\text { Tactile } \\
\text { r value }\end{array}$ & $\begin{array}{c}\text { Individual } \\
\text { r value }\end{array}$ \\
\hline \multirow{2}{*}{$\begin{array}{l}\text { Usefulness of } \\
\text { Mobile learning to } \\
\text { Business English } \\
\text { Language } \\
\text { Course }\end{array}$} & .4325 & -.2345 & .0060 & .4321 & .0373 & -.1280 \\
\hline & $\mathrm{p}=.003^{\star}$ & $p=.432$ & $p=.947$ & $\mathrm{p}=.001^{*}$ & $\mathrm{p}=.679$ & $p=.155$ \\
\hline \multirow{2}{*}{$\begin{array}{l}\text { Acceptability of } \\
\text { Mobile learning to } \\
\text { Business English } \\
\text { Language } \\
\text { Course }\end{array}$} & -.0981 & -.0170 & .0793 & -.1027 & .0419 & -.1061 \\
\hline & $p=.276$ & $p=.850$ & $p=.379$ & $p=.255$ & $p=.643$ & $p=.239$ \\
\hline \multirow{2}{*}{$\begin{array}{l}\text { Perceive } \\
\text { Enjoyment of } \\
\text { Mobile learning to } \\
\text { Business English } \\
\text { Language } \\
\text { Course }\end{array}$} & .0024 & .0355 & .1348 & .567 & .876 & -.1608 \\
\hline & $p=.979$ & $p=.694$ & $p=.134$ & $\mathrm{p}=.002^{*}$ & $p=.001^{*}$ & $p=.073$ \\
\hline \multirow{2}{*}{$\begin{array}{l}\text { Facilitating } \\
\text { Conditions to } \\
\text { Business English } \\
\text { Language } \\
\text { Course }\end{array}$} & .2128 & .2526 & .1179 & -.546 & .768 & -.1460 \\
\hline & $\mathrm{p}=.017^{*}$ & $\mathrm{p}=.002^{*}$ & $p=.190$ & $\mathrm{p}=.000^{\star}$ & $\mathrm{p}=.000^{*}$ & $p=.104$ \\
\hline \multirow{2}{*}{$\begin{array}{l}\text { Behavioral } \\
\text { Intention to } \\
\text { Business English } \\
\text { Language } \\
\text { Course }\end{array}$} & .0060 & -.0231 & -.0811 & .3244 & -.0241 & .797 \\
\hline & $p=.947$ & $p=.798$ & $p=.369$ & $p=.001^{*}$ & $p=.790$ & $\mathrm{p}=.002^{\star}$ \\
\hline
\end{tabular}

For teachers, this course teaches them how to effectively use mobile learning into their lectures. Table 5 shows a high link between m-learning usage and learning outcomes, especially for English language learners. As a result, the idea that student acceptance of mobile learning is linked to their learning methods is approved has been shown correct. Students who favor visual and social learning activities are more likely to assess M-efficacy learning's in business English courses, according to the findings of the research. Students that like social and tactile learning tend to prefer $\mathrm{m}$-learning in the classroom. M-learning is more likely to be adopted in learning settings where students enjoy learning 
in four ways: visually, acoustically, kinaesthetically, and in groups. M-learning will be increasingly popular among students who prefer one-on-one or small-group teaching going forward. Visual and group learners in business English courses likely to embrace M-effectiveness learning's methods well. According to this, students who like graphical and collaborative learning activities will find mobile learning to be particularly beneficial. In order to improve learning results while using e-learning on smart phones, wireless sensors and tablet PCs, visual and collaborative indicators are critical Mobile learning combines a variety of learning modalities to suit the interface characteristics of e-learning techniques (visual, auditory, tactile, and group). Studies have shown a connection between mobile learning and a variety of learning styles (Chen \& Huang, 2020, Mussa,2020). Consequently, tactile and group learners favor mobile learning in business English courses, suggesting that students prefer group learning with a focus on manipulatives. Mobile learning requires collaboration, and students say they like using smartphones and tablets more now that they're in the classroom. Many research has shown the interactive and collaborative nature of mobile learning and how it differs from other forms of education. As a result, learners have access to real-time information, which gives them the freedom to study at a faster or slower pace, depending on their preferences.

It is more probable that students who learn best via the use of their five senses would benefit from using mobile devices for education. Since audio-visual and tactile learning techniques are preferred by certain students, such students will be more likely to use e-learning methods in their business English courses provided they have access to the required equipment, internet connection, knowledge, and support. Enabling conditions have been linked to greater classroom use of mobile learning, according to previous study. M-learning is more likely to be adopted positively by students who prefer collaborative and customized learning techniques. Mobile learning's interactive, collaborative, and private features may benefit students with diverse learning preferences, according to this study. The use of M-learning in the classroom improves student engagement and mood (Qureshi, et al, 2020, Talan, 2020).

\section{Conclusion}

According to the findings of this research, there is a connection between the use of mobile learning and the perceptual learning style preferences of South Americans EFL students enrolled in a business English course. The study's findings indicate that students enrolled in a business English course demonstrate a high degree of adoption of mobile learning technologies. Also discovered were those respondents strongly favor visual learning over other learning styles such as small groups or one-onone instruction, tactile learning over auditory learning, and kinesthetic learning over visual and auditory learning, respectively. It turns out that when learners are broken down by age and gender, the acceptability, utility, pleasure, and Behavioural aim of M-learning are more appealing to male respondents than to female respondents when these variables are taken into account. In terms of age, it was discovered that respondents, regardless of their age, find it attractive and beneficial to utilize $\mathrm{M}$-learning in their business English course. In a similar vein, when respondents are divided into groups based on their gender, no statistically significant variations in learning style preferences are found. Participants in the lower age brackets, on the other hand, express a group learning preference, while those in the older age brackets show a preference for individual learning. It's important to note that the adoption of M-learning and students' preferred ways of learning are statistically linked. Findings show that the more students who utilize M-learning have a preference for learning methods, the more students choose tactile, visual, audio-kinaesthetic, and group learning modalities. The research's results and implications are carefully explored.

\subsection{Contribution of the paper to Literature}

Among South American EFL students, the current study shows a positive correlation between Mlearning adoption and students' learning styles in business English courses, where mobile learning characteristics like blended, ubiquitous and private learning can directly benefit students' learning 
styles to improve learning performance. Gender and age are also important determinants of $\mathrm{M}$ learning uptake and students' learning methods, according to the results. A deeper knowledge of TAM, which says that an individual's impressions of technology adoption are linked to their profiles and personal characteristics in connection to Education 4.0, highlights the significance of this development.

\subsection{Implications}

The study's conclusions have a wide range of applications in the real world as well as in the classroom. The study's aim is to find out how South American English language learners use M-learning and what their learning styles are. Those are the choices you have: Teachers of business English language should be trained to use mobile learning in the classroom as part of the College's faculty development plan. This includes orientation to the M-learning mode for instructors, as well as ongoing enhancement and improvement of the application and developed program. The university's e-learning environment should be improved in order to guarantee that students get the most out of M-learning; language instructors' preparedness for M-learning and the degree of technology adoption should be assessed; and university management should be strongly supported.

\subsection{Implications to Economics of Education}

Investing in education pays off in the long run. The emerging nations in terms of m-learning trend, execution, challenges, and solutions. A non-perspective learner was left out of this research, which focused only on those who utilized the internet for learning purposes. Determining how to attract new users as well as successfully retain current ones may be the subject of future study. Additionally, the effect of m-learning on economic planning in terms of budget allocation and private sector involvement must be investigated. ICT infrastructure and capital investment, including management systems and human resources for ICT enhancement, can serve as a springboard for the education system's sustainable expansion. M-learning is evolving and gaining popularity as a result of its adaptability. This enables the creation of economic value in an uncertain world in a knowledge-based economy. The example demonstrates how institutional and regulatory frameworks are altered to integrate the economy into global market realms. While ICT has had a significant economic impact, our research indicated that we are hampered by inadequate institutional and operational capacities for operating ICT systems. We should not forget that conventional classroom teaching techniques continue to be popular among students and that instructors' roles haven't altered. In addition, since the curriculum is always changing, students prefer to practice utilizing the available tools. This also has an impact on the economy in terms of job possibilities for people and the general public. These are substantial impediments to the growth of ICT, which would promote its spread and mitigate the perils of unguided competition, which would result in lower investment returns. It's possible that as a consequence of this, the actors choosing the supply-led approach instead of the demand-pull strategy will be pushed out.

\subsection{Limitations}

There are some limitations to this study, but they can serve as a springboard for further investigation and validation. It is essential to note that the data used in this study was derived mostly from respondents' self-reports at a single Asian university college, which is a significant flaw in the research. Expanding the number of participating institutions and the number of study samples is necessary to provide more convincing results and to continue education. There should have been additional equitable, individual, and school-related variables included in the study besides gender and age as personal factors. In addition to conventional research techniques, future studies should make use of hybrid research methods and quasi-experimental study designs. 


\section{References}

1. Abouzeid, E., Fouad, S., Wasfy, N. F., Alkhadragy, R., Hefny, M., \& Kamal, D. (2021). Influence of Personality Traits and Learning Styles on Undergraduate Medical Students' Academic Achievement. Advances in Medical Education and Practice, 12, 769.

2. Al-Azawei, A., \& Alowayr, A. (2020). Predicting the intention to use and hedonic motivation for mobile learning: A comparative study in two Middle Eastern countries. Technology in Society, 62, 101325.

3. Al-Emran, M., Mezhuyev, V., \& Kamaludin, A. (2020). Towards a conceptual model for examining the impact of knowledge management factors on mobile learning acceptance. Technology in Society, 61, 101247.

4. Asongu, S. A., Adegboye, A., Ejemeyovwi, J., \& Umukoro, O. (2021). The mobile phone technology, gender inclusive education and public accountability in Sub-Saharan Africa. Telecommunications Policy, 45(4), 102108.

5. Barrafrem, K., Västfjäll, D., \& Tinghög, G. (2020). Financial well-being, COVID-19, and the financial better-than-average-effect. Journal of Behavioral and Experimental Finance, 28, 100410.

6. Bernacki, M. L., Greene, J. A., \& Crompton, H. (2020). Mobile technology, learning, and achievement: Advances in understanding and measuring the role of mobile technology in education. Contemporary Educational Psychology, 60, 101827.

7. Chen, C. C., \& Huang, P. H. (2020). The effects of STEAM-based mobile learning on learning achievement and cognitive load. Interactive Learning Environments, 1-17.

8. Chtourou, M. S., \& Souiden, N. (2010). Rethinking the TAM model: time to consider fun. Journal of Consumer Marketing.

9. Crompton, H., \& Burke, D. (2018). The use of mobile learning in higher education: A systematic review. Computers \& Education, 123, 53-64.

10.Elsalem, L., Al-Azzam, N., Jum'ah, A. A., Obeidat, N., Sindiani, A. M., \& Kheirallah, K. A. (2020). Stress and behavioral changes with remote E-exams during the Covid-19 pandemic: A cross-sectional study among undergraduates of medical sciences. Annals of Medicine and Surgery, 60, 271-279.

11.Fisher, R. A. (1992). Statistical methods for research workers. In Breakthroughs in statistics (pp. 6670). Springer, New York, NY.

12.Ge, Z. G. (2021). Does mismatch between learning media preference and received learning media bring a negative impact on Academic performance? An experiment with e-learners. Interactive Learning Environments, 29(5), 790-806.

13.Islam, M. J. (2011). Language learning style preferences: Bangladeshi EFL learners. Harvest: Jahangirnagar Studies in Language and Literature, 26, 59-76.

14.Jossan, K. S., Gauthier, A., \& Jenkinson, J. (2021). Cultural implications in the acceptability of gamebased learning. Computers \& Education, 174, 104305.

15.Kalloo, V., \& Mohan, P. (2012). Correlating questionnaire data with actual usage data in a mobile learning study for high school mathematics. Electronic Journal of e-Learning, 10(1), pp76-89.

16.Khampirat, B. (2021). The Impact of Work-Integrated Learning and Learning Strategies on Engineering Students' Learning Outcomes in Thailand: A Multiple Mediation Model of Learning Experiences and Psychological Factors. IEEE Access, 9, 111390-111406.

17.Khan, A. I., Al-Shihi, H., Al-Khanjari, Z. A., \& Sarrab, M. (2015). Mobile Learning (M-Learning) adoption in the Middle East: Lessons learned from the educationally advanced countries. Telematics and Informatics, 32(4), 909-920.

18.Khedr, A. E., Idrees, A. M., \& Alsheref, F. K. (2019). A Proposed Framework to Explore Semantic Relations for Learning Process Management. International Journal of e-Collaboration (IJeC), 15(4), 46-70.

19.Laksana, D. N. L. (2021). Implementation of online learning in the pandemic covid-19: Student perception in areas with minimum internet access. Journal of Education Technology, 4(4), 502-509. 
20.Magulod Jr, G. C. (2019). Learning styles, study habits and academic performance of Filipino University students in applied science courses: Implications for instruction. JOTSE: Journal of Technology and Science Education, 9(2), 184-198.

21. Martin, A. (2020). How to optimize online learning in the age of coronavirus (COVID-19): A 5-point guide for educators. UNSW Newsroom, 53(9), 1-30.

22.Muñoz, V. A., Carby, B., Abella, E. C., Cardona, O. D., López-Marrero, T., Marchezini, V., ... \& Wisner, B. (2020). Success, innovation and challenge: school safety and disaster education in South America and the Caribbean. International journal of disaster risk reduction, 44, 101395.

23.Mussa, I. H. (2020). Mobile Learning adoption in the Middle East: Limitations, Challenges and Features of the Mobile Devices. Int. J. Contemp. Manag. Inf. Technol, 1(1), 30-36.

24.Mutambara, D., \& Bayaga, A. (2021). Determinants of mobile learning acceptance for STEM education in rural areas. Computers \& Education, 160, 104010.

25.Naciri, A., Baba, M. A., Achbani, A., \& Kharbach, A. (2020). Mobile learning in Higher education: Unavoidable alternative during COVID-19. Aquademia, 4(1), ep20016.

26.Navarro, O., Sanchez-Verdejo, F., Anguita, J., \& Gonzalez, A. (2020). Motivation of university students towards the use of information and communication technologies and their relation to learning styles. International Journal of Emerging Technologies in Learning (iJET), 15(15), 202-218.

27.Oyelere, S. S., Suhonen, J., Shonola, S. A., \& Joy, M. S. (2016, October). Discovering students mobile learning experiences in higher education in Nigeria. In 2016 IEEE Frontiers in Education Conference (FIE) (pp. 1-7). IEEE.

28.Qureshi, M. I., Khan, N., Hassan Gillani, S. M. A., \& Raza, H. (2020). A Systematic Review of Past Decade of Mobile Learning: What we Learned and Where to Go. International Journal of Interactive Mobile Technologies, 14(6).

29.Ranjeeth, S., Latchoumi, T. P., \& Paul, P. V. (2020). Role of gender on academic performance based on different parameters: Data from secondary school education. Data in brief, 29, 105257.

30.Saikat, S., Dhillon, J. S., Wan Ahmad, W. F., \& Jamaluddin, R. (2021). A Systematic Review of the Benefits and Challenges of Mobile Learning during the COVID-19 Pandemic. Education Sciences, 11(9), 459.

31.Sitar-Tăut, D. A. (2021). Mobile learning acceptance in social distancing during the COVID-19 outbreak: The mediation effect of hedonic motivation. Human Behavior and Emerging Technologies, 3(3), 366-378.

32.Talan, T. (2020). The Effect of Mobile Learning on Learning Performance: A Meta-Analysis Study. Educational Sciences: Theory and Practice, 20(1), 79-103.

33.Talwar, M., Talwar, S., Kaur, P., Tripathy, N., \& Dhir, A. (2021). Has financial attitude impacted the trading activity of retail investors during the COVID-19 pandemic?. Journal of Retailing and Consumer Services, 58, 102341.

34.Tan, T. H., \& Liu, T. Y. (2004, August). The mobile-based interactive learning environment (MOBILE) and a case study for assisting elementary school English learning. In IEEE International Conference on Advanced Learning Technologies, 2004. Proceedings. (pp. 530-534). IEEE

35.Taufina, T., Chandra, C., \& Kharisma, A. (2019, October). Technology integration in thematic learning to welcome the era of the industrial revolution 4.0 in elementary schools. In Proceeding International Seminar of Primary Education (Vol. 2).

36.Tkachuk, V., Yechkalo, Y., Semerikov, S., Kislova, M., \& Hladyr, Y. (2020, October). Using mobile ict for online learning during covid-19 lockdown. In International Conference on Information and Communication Technologies in Education, Research, and Industrial Applications (pp. 46-67). Springer, Cham.

37.Turri, J. (2020). A Peculiar and Perpetual Tendency: An Asymmetry in Knowledge Attributions for Affirmations and Negations. Erkenntnis, 1-14.

38.Yuan, Y. P., Tan, G. W. H., Ooi, K. B., \& Lim, W. L. (2021). Can COVID-19 pandemic influence experience response in mobile learning?. Telematics and Informatics, 64, 101676. 